\title{
Gerçek Bir Âlim, Mümtaz Bir Şahsiyet: Sabri Fehmi Ülgener
}

\author{
Mustafa Acar ${ }^{1}$ \\ Hüsnü Bilir ${ }^{2}$ \\ ${ }^{1}$ Aksaray Üniversitesi ve Kırıkkale Üniversitesi, İktisadi ve İdari Bilimler Fakültesi. \\ ${ }^{2}$ Aksaray Üniversitesi ve Gazi Üniversitesi, Sosyal Bilimler Enstitüsü.
}

\begin{abstract}
Özet
Sabri Ülgener ülkemizin yetiştirdiği, bir elin parmakları kadar az sayıdaki değerli ilim adamından biridir. Ülgener, tarih, gelenek ve maneviyat ışığında kendimizi anlamak ve geleceğe yön verme arayışı bağlamında Muhafazakâr Düşünce geleneğinin de ağır toplarından biridir. Bu çalışmada, öncelikle Sabri Ülgener'in hayatına ve çok yönlü kişiliğine değinilecek; daha sonra temel eserleri ele alınacak, metodolojisi ve zihniyet dünyası incelenecektir.
\end{abstract}

Anahtar Kelimeler: Sabri Ülgener, Weber, İslam, kapitalizm, zihniyet.

\section{A Genuine Scholar, An Outstanding Intellectual Figure: Sabri Fehmi Ülgener}

\begin{abstract}
Sabri Ülgener is one of the few -not more than a handful of- great scholars of our country. Ülgener is also one of the leading figures of the Conservative Thought in pursuit of understanding ourselves and shaping the future in light of the history, tradition and morality. In this paper, we will firstly talk about Sabri Ülgener's life and versatile character; then his basic works will be discussed with a focus on his methodology and mentality.
\end{abstract}

Key Words: Sabri Ülgener, Weber, Islam, capitalism, mentality.

\section{Giriş}

Sabri F. Ülgener Türkiye'nin yetiștirdiği, çok az sayıdaki değerli ilim adamı, iktisatçı, sosyolog ve sosyal bilimciden biridir. Cemil Meriç’in İbn Haldun için söylediği "kendi semasında tek yıldız" deyimini Ülgener için yeniden söylersek, onun için "ilim dünyamızın en parlak yıldızlarından biri, hakiki bir âlim ve seçkin bir sîmâ" diyebiliriz.

Bir ilim adamı, iktisatçı, tarihçi ve sosyolog olarak Sabri Ülgener'i önemli kılan birçok özelliği vardır. Her biri ayrı ayrı incelemeye konu teşkil edebilecek bu özellikler arasında şunları sayabiliriz: İlmi tahlillerinin derinliği; Batıyı da Doğuyu da iyi tanımas1; Ortaçağdan Yeni Çağa, Feodalizmden Kapitalizme geçiş sürecini bir zihniyet dönüşümü çerçevesinde açıklaması; toplumsal dönüşüm ve iktisadi gelişme sürecinde maddi unsurların yanı sıra manevikültürel unsurların rolüne ve bu kapsamda "ekonomi zihniyeti"ne vurgu yapması; kendi dinamiklerimize dayalı yeni bir gelişme modeline olan ihtiyaç bağlamında ahlâk, zihniyet ve İslâm iktisat siyaseti sorunlarıyla yakından ilgilenmiş olması; ve nihayet, bir ilim adamı olarak kılı kırk yaran, ince eleyip sık dokuyan titizliği. İktisadi gelişme, çözülme ve geri kalmışlık, ideolojilerin, hayata bakışın ve manevi-kültürel dinamiklerin toplumsal gelişim üzerindeki rolü ve zihniyetin önemi konularında rahmetli Ülgener bize, her biri yolumuza 1şık tutacak, okunmaya ve irdelenmeye değer çok kıymetli eserler bırakmıştır.
Ona göre insanların üretim, tüketim, tasarruf ve yatırım kararları dünya görüşünden, topluma egemen olan âdet, anane, gelenek, görenek ve inançlardan bağımsız değildir. Marx'ın altyapı kurumu olarak maddi-ekonomik faktörlerin belirleyici olduğu fikrine karşı, manevi-kültürel dinamiklerin daha önemli olduğunu savunan Weberyen geleneği izleyen Ülgener, ekonomi zihniyetinin Batı ve Doğunun farklı patikalar izlemesinde büyük rol oynadığı kanısındadır. Ona göre, Ortaçağ ekonomi zihniyeti üzerinde "huzur-u kalp", "bâtın imareti" gibi basit ilkelerle zihinlere nüfuz etmiş olan tasavvuf ve özellikle Bâtınilik cereyanları önemli ölçüde etkili olmuştur. Fütüvvet, ahilik gibi birçok kavramın hem klasik ahlâk eserlerinde ve hem de dini-tasavvufi kitaplarda hemen hemen aynı şekillerde kullanılması, ekonomi ve din alanı arasında yakın ilişkilerin mevcut olduğuna işaret etmektedir.

Ülgener'e göre iktisadi çözülmemizde etkili olan insan tipi, ferah yaşamanın tattıracağı haz ve zevkin yabancısı olmamakla birlikte, bu amaca ulaşma konusunda acele ve telaştan hoşlanmayan, yolunu ve yönünü tayinde görenek ve otorite bağları ile çevrili, dışa ve "yaban”a kapalı, ve nihayet, işinde ve hesabında "götürü", insan tipidir.

Batıda Rönesans ve Reform hareketleri, beşeri aklın bütün manevi, ruhani otoritelerini yıkarak, bireyi din ve sanat alanında "vahiy ve ilhamını Allah'tan aracısız alma" olarak

\footnotetext{
${ }^{1}$ İnce hesap yapmayan, üstünkörü hesapla idare eden, hesapl 1 ve sistematik olmaktan uzak.
} 
değerlendirilebilecek bir olgunluk seviyesine kavuşturmuştur. Bu sayede iktisadi hayatta rasyonalizmin temelleri atılmış; bu alanda da artık sanatın üzerindeki kalın esrar perdesi kalkmış, her sanatın, diğer ilimler gibi görenekle, eskileri taklit ederek değil, aklın ve mantığın yardımıyla öğrenilebilmesi kolaylaşmıştır. $\mathrm{Bu}$ tür bir zihniyet dönüşümü Batının toplumsal dönüşümüne damgasını vurmuştur.

$\mathrm{Bu}$ çalışma, ilim ve düşünce hayatımızın bu mümtaz şahsiyetinin hayatı, eserleri ve metodolojisini konu almaktadır. İzleyen bölümde Ülgener'in hayatı ve düşünce dünyamızda iz bırakan çok yönlü kişiliği ele alınmaktadır. Üçüncü bölümde her biri düşünce ve kültür dağarcığımıza önemli bir katkı niteliğindeki eserleri irdelenmektedir. Dördüncü ve son bölümde ise, Ülgener'in metodolojisi üzerinde durulmaktadır.

\section{Sabri Ülgener'in Âlim Kişiliği ve Hayat Hikâyesi}

Osmanlı Devleti'nin son yıllarını yaşamış, Türkiye'nin iktisadi-sosyal tarihi konusunda önemli eserler bırakmış bir iktisatçı ve sosyal bilimci olan Sabri Fehmi Ülgener, Türk düşüncesinde iktisat ve sosyoloji arasındaki ilişkiye yeni bir ivme kazandırmıştır. Ancak, Ülgener'i sadece iktisatçı ve sosyolog olarak adlandırmak ve onun ilmi kimliğini bu iki alanla sınırlamak, bu nev-i şahsına münhasır keskin zekâya biraz haksızlık olacaktır. O ufku geniş, gözlem ve tespitlerinde dikkatli, meselelerin çok boyutlu karmaşık yapısının farkında, İslâm düşüncesini de Batı düşüncesini de ihata etmiş, analiz ve sentez kabiliyeti yüksek, gerçek bir âlimdir.

Nitekim, yine çok kıymetli değerlerimizden biri olan rahmetli sosyolog Erol Güngör'e göre Sabri F. Ülgener, "memleketimizde bir elin parmakları kadar az sayıdaki ilim adamlarından biri"dir. Metot konusunda hâlâ tek başına zirvede durmaktadır (Akyol, 1983; Akt: Koçdemir, 1998: 107). Kendisini tamamılla mesleğine vermiş; mevki, ikbal ve her hangi maddi bir hedef peşinde koşmamış, çok iyi ahlâklı, aynı zamanda mütevazı kâmil bir insandır (Sarc, 1987: 1).

Ülgener, tecessüsü tek bir alana odaklanmış biri değildi; sosyal bilim yelpazesinin hemen her alanına uzanan geniş bir tecessüsün sahibiydi. Bu bağlamda Ülgener, iktisatçı olduğu kadar, iktisat felsefecisi, kültür bilimcisi, sosyal tarihçi, sosyolog ve metodolog idi (Ertüzün, 1987: 13-14). Eserlerini alıcı gözüyle inceleyen herkesin kolaylıkla fark edeceği gerçek, Ülgener'in esasen iktisadın felsefeden, tarihin sosyolojiden, kültürün sosyal hayattan bağımsız olmadığını kavramış, bunlardan biri hakkında bir şeyler söyleyebilmek için ötekiler hakkında da epey bilgi sahibi olmak gerektiğini kavramış bir bilim adamı olduğudur. $\mathrm{Bu}$ çerçevede Ülgener'in çok yönlü ve çok boyutlu ilim adamlığına vurgu yapan Uğur'a (1983) göre Ülgener, iktisattan sosyolojiye, sosyolojiden tarihe ve hatta ilahiyata kadar uzanan çeşitli disiplinlerin verilerini zihniyet araştırmalarında kullanabilen, bütün bu alanları birbiriyle ilişkilendirebilen, iktisatçılığı, tarihçiliği ve sosyologluğu kendi bilimsel şahsiyetinde bir araya getirebilmiş ve Türk sosyal bilim geleneğinde örneğine az rastlanan bir bilim adamıdır (Akt: Özkiraz, 2007: 36).

Sabri Ülgener, Osmanlı'nın son demlerini yaşadığı 1911 yılının Mayıs ayında İstanbul'daki Fatma Sultan Camii dergâhında doğdu. Mehmet Fehmi Efendi ile Emine Behice Hanım'ın ikinci çocukları olarak dünyaya gelen Ülgener'in dedesi İsmail Necati Efendi Nakşibendî şeyhlerinden olup, babası Mehmet Fehmi Efendi de bu tarikat terbiyesi ile yetişmiş değerli bir zattır (Torun ve Duran, 2010: 64). Bu muhit içerisinde dedesinden tasavvufa meyleden yanını geliştirdi. Baba Mehmet Fehmi Efendi'den şer-î ilimler ile hüsnü hat öğrendi.

Ülgener, İstanbul Erkek Lisesinde orta tahsilini sürdürürken yabancı dili Almancaydı. Evde Arapça ve Farsça ile kurulan yakınlık Almancaya sıçradı. İstanbul Erkek Lisesinden mezuniyetinin ardından İstanbul Darülfünunu (Üniversitesi) Hukuk Fakültesine girdi. Ülgener, babasından İslâmî "norm"u öğrenirken diğer taraftan fakültede ticaret hukuku derslerinde gördüğü hukuk kuralları ve rekabete dair hükümler ve iktisat derslerinde okuduğu piyasa mekanizmasıyla fiyatın serbestçe teşekkülüne ait teorik bilgileri öğreniyor, bu farklı iki "norm"u birleştiriyordu. Daha o yıllarda dış dünyada saflaşma ya da yolların ayrılması gerçeğini yapay bulmaya başladı. İlk yakaladığı gerçek, sathi de olsa tek yanlılığın şu veya bu istikametine kırılmak değil, belki "norm"ların uygunluğundan hareketle yeni bir "norm""reel" çatışmasının içine girmek onun için daha hayırlı olacakt1 (Sayar, 2008: 124).

Ülgener 1935 yılında İstanbul Üniversitesi Hukuk Fakültesinden mezun oldu ve aynı Fakültenin İktisat ve İçtimaiyat Enstitüsüne asistan oldu (Özkiraz, 2000: 32). Bu dönemde Almanya'da Hitler'in zulmünden kaçan bir grup Alman bilim adamı (sosyal bilimciler) bu fakültede ders vermekteydiler. Ülgener, kürsünün Ordinaryusu Prof. Neumark'dan başka, Prof. Röpke, Prof. Rustow ve Prof. Kessler ile de uzun zaman beraber çalışmış, adı geçen profesörlerin ders takrirlerini, kitaplarını, konferans ve makalelerini başarı ile Türkçeye çevirmiştir (Yörük, 1987: $\mathrm{XV})$. Bu fakültedeki Alman hocalar Ülgener'in gelecekte yazacağı eserlerine ilham kaynağı olmuşlardır. Onların etkisi Ülgener'in pek çok eserinde hissedilebilmektedir (Torun ve Duran, 2010: 65).

1938'de askerlik görevine çağrılıncaya kadar İstanbul Üniversitesi Hukuk ve İktisat Fakültelerinde namzet asistan olarak çalıştı. 1939'da İktisat Fakültesi Sosyoloji ve Komün Bilgisi asistanlığına asaleten tayin oldu. 1941 yılında Kapitalizmden Evvel İaşe Buhranları başlıklı doçentlik teziyle "Maliye ve Umumi İktisat Teorisi" kürsüsü doçentliğine atandı. Aynı yıl İktisat Fakültesi Mecmuasında ilk ilmî makalesi yayımlandı: "İktisadi Hayatta Zihniyetin Rolü ve Tezahürleri” (Sayar, 2008: 125). 1943 y1lında ikinci kez üç ay müddetle ordu hizmetine alındı. 1943 yılının ocak ayında annesini, nisan ayında da babasını kaybetti.

Ülgener 1946-1947 yıllarında Harvard Üniversitesinde bulundu ve J. A. Schumpeter ve A. H. Hansen gibi iki büyük iktisatçı ile temas etme imkânı buldu. 1948-1949 akademik yılı başlayana kadar İktisat Fakültesinin sağladığı maddi destekle önce İngiltere'ye geçti. Londra'da 'London School of Economics"te çalıştı. Sonra Hollanda'ya geçti, Amsterdam'da bir kongre'ye katıldı. Nihayet akademik yıl başlamadan önce 1948'de Türkiye'ye döndü (Sayar, 2008: 125).

İktisat Fakültesi'nde 1941'de doçent 1951'de profesör olan Ülgener, iki kez de fakülte dekanlığı yaptı (Torun ve Duran, 2010: 65). Sayar'dan (2008: 126) aktaracak olursak:

"Ayrıca fakültedeki mesai saatlerinin içinde ayda dört saat Yapı ve Kredi Bankası Murakıplığına atandı ve bu görevi yaklaşık bir yıl sürdü. 1958 yılında Sevim Aytaç ile evlendi. Evliliğinin ilk aylarında, Mayls 1958'de, bir akademik yıl kalmak üzere Münih'e gitti. Münih'te mesleki temaslarda 
bulundu, ilginç bulduğu konferans ve seminerleri takip etti ve zamanının önemli bir kısmını üniversite kütüphanesinde geçirdi. 1959 yılında Avrupa'nın çeşitli ülkelerine uğrayarak, Türkiye'ye döndü."

1965 Ağustos ve Eylül aylarında Almanya'da çalışan Türk işçilerinin iktisadi ve sosyal durumlarının araştırılması için Prof. Dr. Haydar Turgaç'la birlikte 1 aylığına yurt dışına çıktı. 1970'li yıllarla birlikte bazı can ve gönül dostlarının vefatı ile Sabri Ülgener, kendi yalnızlığını derinden duymaya başladı. 1974 yılında eşi hastalandı ve uzun bir tedavi sürecinin sonunda sağlığına kavuştu. Eşinin rahatsızlığını takiben kendisi bir kalp krizi geçirdi. 1976 yılında yapılan operasyonla kalbine pil takılan Ülgener, 1981 yılında emekli oldu. Erenköy'deki evinde tam bir itikâfa çekildi. Emekliliği döneminde ilmî çalışmalarına ara vermeden devam eden Ülgener, vaktinin büyük bir kısmını evinde geçiriyor, pek nadir de olsa şehre iniyor, sevenleri ise Erenköy'e geliyordu. Sıhhat durumunun gayet iyi olduğu bir dönemde Ülgener, 30 Haziran 1983 gecesi uykuda geçirdiği kalp kriziyle rahmet-i rahmana kavuştu (Sayar, 2008: 127-128).

Kısacası, Sabri Ülgener 1910 kuşağının Türk düşünce dünyasında yarattığı kırılma noktalarından biridir. Cumhuriyeti 1880 kuşağı ilan etti; 1900 kuşağı kurdu ve 1910 kuşağı eleştirdi. Cumhuriyetin kurucuları arasında yer alan Ziya Gökalp, Osman Nuri Ergin, Yahya Kemal Beyatl1, Fuad Köprülü, Abdülbaki Gölpınarlı, Peyami Safa, Hilmi Ziya Ülken, Ahmet Hamdi Tanpınar gibi isimler 1910 kuşağının doğduğu düşünce dünyasını biçimlendirdi. Bunlardan Ömer Celal Sarc, Ülgener'in Hukuk Fakültesi'nde hocalığını yapmış; Ömer Lütfi Barkan ve Ziyaeddin Fahri Fındıkoğlu gibi isimler bilfiil Ülgener'le birlikte çalışmışlardır. 1940'larda düşünce dünyamıza giren 1910 kuşağı ise, Cumhuriyet yönetiminin fikri taşıyıcılığını yapmış hocalarından farklıdır. 1900 kuşağının belirli bir hedef doğrultusunda bütünleşen fikirleri, 1940'lı yıllarda kırılmalar yaşamaya başlamıştır. 1910 kuşağının sosyal bilimler alanında Niyazi Berkes, Mümtaz Turhan, Nurettin Topçu, Behice Boran ve Kemal Tahir gibi önemli temsilcileri vardır. Sabri Ülgener'in de içinde yer aldığı bu kuşak, zaman içinde düşünsel farklılıklarını ve siyasi taraflarını hocalarının tersine netleştireceklerdir (Yazıcıoğlu, 2008: 2).

\section{Sabri Ülgener'in Eserleri ve Zihniyet Dünyası}

Keynesçi iktisat düşüncesinin ve makro ekonomi öğreniminin Türkiye'de sistematik hale getirilmesinin öncülerinden olan Ülgener, Max Weber'in, Batı Avrupa'da Protestan ahlâkının kapitalizmin ruhu ile örtüştüğü görüşünden yola çıkarak din, ahlâk ve ekonomi ilişkisini Müslüman dünyası açısından ele almıştır.

Ülgener'in ilk bilimsel makalesi, "İktisadi Hayatta Zihniyetin Rolü ve Tezahürleri” adlı makalesidir. Ülgener, ilk yazılarından itibaren bütün entelektüel ilgisini bu iki temel alanda ve onların birbirleriyle olan ilişkileri üzerinde yoğunlaştırmıştır. Ardında bıraktığı yedi kitaptan birisi olan Milli Gelir, İstihdam ve Iktisadi Büyüme adlı eseri, iktisatçı akademisyen kimliğine uygun bir ders kitabı niteliğindedir. Ülgener'in düşünce dünyamıza asıl katkısını yansıtan diğer eserleri ise şunlardır: İktisadi Çözülmenin Ahlâk ve Zihniyet
Dünyası (1981)²; Zihniyet ve Din (1981); Zihniyet Aydınlar ve İzm'ler (1983); Darlık Buhranlarl ve İslâm Íktisat Siyaseti $(1984)^{3}$.

Bu çalışmada, Ülgener'in eserleri 2006 yılında Derin Yayınları tarafından yayımlanan ve "Sabri Ülgener: Toplu Eserler" başlığı altında toplanan beş kitap çerçevesinde incelenmiştir. Ayrıca Der Yayınları tarafından 1995 yılında basılan Milli Gelir, Istihdam ve İktisadi Büyüme adlı eser de ele alınmıştır.

Ülgener'in eserlerinden Milli Gelir, Istihdam ve Íktisadi Büyüme adlı çalışması, daha önce de belirtildiği gibi, ders kitabı niteliğindedir. Keynesgil sistemi anahtar bir model olarak ele aldığı bu kitabında Ülgener, Keynes-Hansen modelinin, gelişmişliğin ve azgelişmiş̧liğin insan ve tarih birikimiyle tutarlılığını incelemiştir. Keynes mantığına göre iç iskeletini inşa ettiği bu eseri, aslında onun 1946-1948 yılları arasında Amerika'da Harvard Üniversitesi'nde derslerine katıldığı Profesör A. Hansen'e ve onun Keynes'in Genel Teori' sinin başarılı bir vulgarizasyonu olan A Guide to Keynes'e çok şey borçludur. İşsizlik sorununun çözümünde politikacının dikkatini, ekonominin reel performansının belirleyiciliği üzerine çeken Keynesgil eksik-denge anlayışı ülkemize ilk defa, sistemli ve sağlıklı bir tahlille, Profesör Ülgener tarafından getirilmiştir (Sayar, 1987: 28). Ülgener, bu eserin önsözünde kitabın yazılış amacını şu şekilde açıklamaktadır:

"Kitabı yazarken en fazla ehemmiyet verdiğim husus, ele alınan bahisleri her defa az gelişmiş bir ekonominin meselelerine uydurmak ve tatbik etmek olmuştur. Milli gelir, istihdam ve iktisadi büyüme gibi milli iktisadın kaderi ile pek yakından ilgili bir konuda ileri sürülen fikirleri sadece gelişmiş ve olgun ekonomiler için tasarlanan şekli ile izah edip geçmeye gönlüm ve kalemim varmad. Her bahsi, istisnasiz olarak, az gelişmiş veya yeni gelişmekte olan bir ekonominin meselelerine kaydırmayı kendimce bir meslek borcu saydım... meselelerin değişik bir açıdan vaz'ı ve okuyucuya o yolda düşünme firsatının kazandırlması fikrimce problemin tam ve kesin çözümü kadar ehemmiyetli ve faydalıdır."

1951 y1lında İstanbul Üniversitesi İktisat Fakültesi'nde "Profesörlük Tezi" olan Tarihte Darlık Buhranları ve Íktisadi Muvazenesizlik Meselesi adlı eser, adından da anlaşılacağı üzere, tarih sahnesinde yer alan darlık buhranları örnekleri, bunların sebepleri ve özelde yine Osmanlı ayağı üzerinde durmaktadır. $\mathrm{Bu}$ eserinde Osmanlı'dan Cumhuriyet Türkiye'sine değin yaşanmış olan çarpıcı darlık dönemleri anlatılmaktadır (Deniz, 2009: 5). Eser üç kısımdan oluşmaktadır. Birinci kısım, iktisadi dengesizliğe değişik haller ve şartlar altında verilen isim ve tarifler ile, bu konuda ortaya atılan fikirlere tahsis edilmiştir. İkinci kısımda, vakalar ve örneklere yer verilmiştir. Üçüncü kısımda ise, iktisadi dengesizliğin dünü ile bugünü arasındaki kıyaslamalar yer almakta ve sonuçlar ortaya koyulmaktadır. Kaynakları itibariyle incelendiğinde ise, bu eserin, Werner Sombart, J. Schumpeter, A. Spiethoff, G. Shmoller, Max Weber, A. Salz, Max Wirth, F. Schaffle, G. V. Below gibi çok tanınmış simaların eserlerinin yanı sıra Pîrîzâde, Ahmet Refik, Ahmet Rasim, Fuat Köprülü'nün çok değerli telifleri ile Asım Tarihi,

\footnotetext{
${ }^{2}$ İlk baskısı, Iktisadi Inhitat Tarihimizin Ahlâk ve Zihniyet Meseleleri başlığıyla 1951'de yapılmıştır.

3 İlk baskısı Tarihte Darlık Buhranları başlığıyla 1951'de yapılmıştır.
} 
Selâniki Tarihi, Naimâ Tarihi, Cevdet Tarihi, Solakzâde Tarihi, Silâhtar Tarihi, Raşit Tarihi, Şânizâde Tarihi gibi müstesna tarihi hazineler ile Osman Nuri Bey'in ünlü Mecelle-i Umur- $u$ Belediye'si gibi bilhassa Osmanlı tarihi ile ilgili belli başlı hemen bütün eserlerden meydana geldiği görülmektedir (Tuna, 1987: 8).

Osmanlı toplumunda yaşanan darlık buhranlarından, bu buhranların sebep ve sonuçlarından bahseden Ülgener, konuyu daha da somutlaştırmak için, 16. ve 17. yüzyılda Osmanlı Devleti'nde yaşanan buhranlardan söz ettikten sonra, buhranların sebeplerine ve sonuçlarına da değinmiştir. Ülgener buhranların sebeplerini iki önemli başlık altında vermiştir. Bunlardan ilki "temelli ve uzun vadeli sebepler", ikincisi ise "boşaltıcı ve hızlandırıcı faktörler"dir. Uzun vadeli sebepler arasında, nüfus artışı ve bunun neticesinde meydana gelen köylerden şehirlere yaşanan göçler, paranın değerinde yaşanan dalgalanmalar ve uzun süren savaşlar ve bu savaşlar için yapılan masraflar yer almaktadır. Boşaltıcı ve hızlandırıcı faktörler arasında kıtlık ve ihtikâr ${ }^{4}$ yer almaktadır. Kıtlık sebepleri biri tabii, diğeri siyasi, idari ve mali olmak üzere iki büyük grupta toplanabilmektedir. İhtikâr, malın piyasada azaldığı veya arttığı dönemlerde bazı insanların malı piyasadan çekerek veya piyasaya sürmeyerek, fiyatının artmasına neden olmalarıyla meydana gelmektedir. Tüm bu iktisadi bunalımların sonucu ise, toplumda yaşanan panik, telaş ve bir kaos ortamının oluşmasıdır (Ülgener, 2006a: 75-103).

Ülgener düşüncesinin damıtıldığı İktisadi Çözülmenin Ahlâk ve Zihniyet Dünyası (İktisadi İnhitat Tarihimizin Ahlâk ve Zihniyet Meseleleri) kitabı, geri kalmışlığın nedenleri ve geri kalmışlıktan kurtuluş yolları üzerine odaklanmıştır. Ülgener'e göre geri kalmışlık "Yakın Şark" medeniyetinin özüne ilişkin bir sorundur ve feodalizmden kapitalizme geçmek için gerekli olan zihniyet değişiminin yaşanamamış olmasından kaynaklanmaktadır. Kapitalizme ilk güdüyü verecek insan, Türkiye'de kapitalizme geçişi sağlayacak zihniyetin taşıyıcılığını yapamamış ve dolayısıyla Ortaçağ zihniyetine geri dönüş yaşanmıştır. Esnaflaşma ve içe kapanma olarak gördüğü Ortaçağ zihniyeti de Osmanlı ekonomik ve toplumsal düzeninde bir inhitata, yani çözülüşe neden olmuştur (Yazıcıŏlu, 2008: 4). Ülgener Osmanlı ile Batı arasında meydana gelen farkı şu sözlerle izah etmektedir:

"Geriye bakarak artık rahatlıkla söyleyebiliyoruz ki, kazanma gayreti, kabına sığmayan macera hevesi prekapitalist ${ }^{6}$ dünyanın hiçbir zaman yabancısı olmamıştır. Bütün mesele doku altında birikmiş bu ihtirasın (insanın yaradılışının neredeyse o değișmez - "constant”- diyeceğimiz temel özelliğinin) zamanla nereye doğru yol almış olacağını kestirebilmekten ibarettir. Batı ile ayrılış noktasinı da burada aramak gerekecekti: Biri temelde normal ve mutat kazanç imkânlarını kaybederek sonunda ister istemez loş ve sapa yollara yönelirken, öbürü kapitalist organizasyon ve hukuk formlarının kuruluşu ile birlikte dar ve eğri yollardan düzlüğe çıkmanın yönünü ve yönetimini bulmuş oluyordu" (Ülgener 2006b: 256).

\footnotetext{
${ }^{4}$ Gömüleme, spekülatif amaçlarla malı piyasadan çekme, saklama, karaborsacılik.

5 Ülgener Yakın Şark'ın sınırlarını Orta Anadolu, Suriye, Kuzey Irak ve Batı İran'1 kapsayacak şekilde çizmektedir.

${ }^{6}$ Kapitalizm öncesi.
}

Dinin iktisadi ve ahlâki hayat üzerindeki etkisini açıkladığı Zihniyet ve Din: İslâm, Tasavvuf ve Çözülme Devri İktisat Ahlâkı adlı eser Max Weber'in din sosyolojisi ve özellikle Protestan Ahlâkı ve Kapitalizmin Ruhu üzerindeki çalışmalarının uzantısı ve tamamlayıcısı sayılabilir. Ülgener İslâm dini ve tasavvuf bahsine ağırlık verdiği bu eserinde, konuyu, Weber'de eksik bırakılmış tarafa, İslâm dünyasına aktarmayı hedef almıştır (Tuna, 1987: 10). Ülgener iktisat ahlâkının, zamanının genel düşünce yapısından ayrı düşünülemeyeceği kanısındadır:

“...iktisat ahlâkı diye çă̆ın genel ahlâk normları dışında ve onlardan ayrı bir disiplinden söz edecek değiliz; olsa olsa geniş kapsamı içinde sosyal ahlâkın günlük ihtiyaç tatminine bakan yüzü ile karşı karşıya olduğumuzu söyleyebiliriz. İster geniş ister dar çerçevesi içinde alınsin varllacak tarif hepsi için birdir: Iktisat ahlâkl, gündelik tavır ve davranışlarımı üzerine -

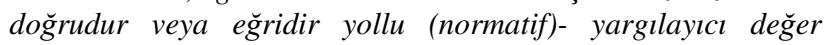
hükümlerinin söz ve deyim halinde ifadelendirilmiş bütünüdür" (Ülgener, 2006c: 19).

Ülgener'in, İktisadi Çözülmenin Ahlâk ve Zihniyet Dünyast ve Zihniyet ve Din: İslâm, Tasavvuf ve Çözülme Devri Iktisat Ahlâkı eserlerinde zihniyet, din ve iktisat ahlâkı gibi kavramlar üzerinde durduğu görülmektedir. Bu iki eserde incelediği hususları Ülgener şu şekilde açıklamaktadır:

“...Ortaçağ sonlarından bu yana iktisat ahlâkı ve zihniyeti -

kültür tarihimiz boyunca süregelen akisleri ile-nasil bir çehre gösterir? Zihniyeti yüzyıllar süresince doyuran, akış ve yayılışına hız katan çeşitli etkenler (din faktörü dahil) nelerdir? İşte cevaplarını arayacağımız başlıca sorular bunlar olacaktır. Her iki soru, birbirine mantıken bağlı görünmekle beraber, ayr ayr ele alınabilir ve alınmast bizce daha da yerinde olur. Zihniyet gibi gerçekten karışık bir yı̆̆ını daha ilk adımda, köklerine doğru takibe koyulmadan evvel, onu kendi içinde bir bütün olarak tanımakta yarar vardır. Araștırmamızda biz de önce konunun bu ilk bölümünü ele alacağız. Zihniyetin kökleri ve manevi-dini akımlarla alakası ayrı bir incelemede gözden geçirilecektir" (Ülgener, 2006b: 9-10).

Ülgener, Zihniyet, Aydınlar ve İzmler adlı eserinde ise, ortaçă̆ iktisadi zihniyetinden hareketle Osmanlı iktisadi yapısını incelemiş ve Batılı ve Türk aydınları son derece mantıklı ve tutarlı bir şekilde karşılaştırarak Türk aydınlarının eksikliklerini sıralamış ve ülke aydınlarını âdetâ bir iç hesaplaşmaya davet etmiştir. Ülgener'in bu eseri üç bölümden oluşmaktadır. "Zihniyet Araştırmaları" başlıklı ilk bölümde, zihniyet konusundaki denemelere yer verilirken, "Aydınlar" başlıklı ikinci bölüm ise "Aydınlar Sosyolojisi ve Çağımız Aydını" ve "Marksizm ve Aydınlar (Bilim, İdeoloji ve Marksizm)" başlıklı iki denemeden oluşmaktadır. "Sloganlar ve İzm'ler" başlığı taşıyan üçüncü bölüm de, "Slogan Çağı ve İzm'ler Savaşı” ile "İzm’ler ve Sistemler (Bir İzm'in Dünü ve Bugünü)" olmak üzere iki kısımdan oluşmaktadır. Ülgener, bu eseri kaleme alma ihtiyacını -bir anlamda da mecburiyetini- şu şekilde ifade etmektedir:

“...Birikimin ilk sonucunu 1951'de alabildik: Yıllar içinde düsse kalka ve bir hayli doğum sancisı ile nihayet "Iktisadi Inhitat Tarihimizin Ahlâk ve Zihniyet Meseleleri" yayınland. Bunu arkadan zihniyetin dinî-tasavvufî kökleri ve kaynakları üzerine ikinci bir inceleme izleyecekti... Bütün bu zorluklar üst üste biriktikçe yıllar yılı konuya dönmek mümkün olmadı. Belki de hiç dönmeyecektim. Ama arada elim değip birikmiş notlara göz gezdirdikçe bir zamanlar yazıp bozup bir kenara attıklarıma acınarak bakmaya başladım... eldeki yı̆̆ına bir kere daha eğilince bir kısım notların -çoğu metodoloji ve uygulama ile ilgili- ne birincisine ne ikincisine yedirilemeyen boşlukta 
bırakıldı̆̆ını gördüm. Onların da dosya ve zarflar içinde uyuklayıp kalmalarına gönlüm razı olmadı. Bunca zaman zindan hayatı yaşattığım bu dağınık notları da şimdi iyi kötü giydirip kuşatıp gün ışı̆̆ına uğurlarken arkalarından "yolunuz açık olsun!" diyorum" (Ülgener, 2006d: 4-6).

Son olarak, Ahmed Güner Sayar tarafından Ülgener'in makalelerinin $^{7}$ derlendiği Makaleler adlı eser bulunmaktadır. Ülgener'in makalelerinin, İktisadi düşünce tarihi yazıları, İktisat teorisine dair yazıları, İktisat Politikası yazıları, İktisadi Sistemler, İktisat Zihniyetine dair yazılar, Konferans ve Söyleşiler, Kitap Tahlil Yazıları, Nekroloji Yazıları şeklinde sınıflandırıldığı bu eserde 93 adet makale yer almaktadır. Eseri yayına hazırlayan Sayar eserin önemini şu şekilde açıklamaktadır:

“Epey zamandır Ülgener'in muhtelif dergilerde çıkmış yazılarının bir araya getirilemeyişinin üzüntüsünü duyardım. "Toplu Eserleri"nin yayılanmaya geçilmesiyle üzüntü yerini sevince bıraktı... (bu kitapta) yer alan yazılar araştırıcılar için ışık salan bir cevher hükmündedir. Sabri Ülgener'in hayırla ve rahmetle yâd ederken bugün bilhassa zihniyet meselesinde, rasyonelleşme yolunda ăgır aksak gidiyorsak onun bıraktığ ipuçlarıyla koltuk değneklerimizi atacağımıza inanıyorum" (Ülgener, 2006e: IX).

\section{4. Ülgener'in Metodolojisi: Weber'ci Yaklaşımla Weber'i Eleştirmek}

Ülgener'in metodolojisini anlamak, Ülgener'i ve düşünce dağarcığımıza katkısını anlamak bakımından oldukça kritik bir önem taşımaktadır.

Eskiler, metodun, yol ve yordamın önemini vurgulamak üzere, "usûl olmadan vusûl olmaz" demişler. Yol olmadan hedefe varılmaz, yöntem olmadan sonuca ulaşılmaz. Yani metodoloji, yöntem, bilimsel tahlil için gidilecek yol, kullanılacak araçlar, esas alınacak model ve varsayımlar önemlidir. Bu anlamda Ülgener metodoloji meselesi üzerinde en çok durmuş olan ilim adamlarımızdan biridir. Ülgener'in metodolojisine önemle vurgu yapan Y1lmaz'a (2003: 492) göre Ülgener, ilgilendiği konular kadar, o konuların gerektirdiği yöntem itibariyle de döneminin sosyal bilimcileri arasında müstesna bir yere sahip olmuştur. Dönemin Türkiye'sinde hâkimiyetini devam ettiren Gökalp-Durkheim çizgisinin pozitivizmine karşı, Ülgener Alman Tarih Okulu'nun Weber ve Sombart ile beraber ele alındığı, anlamac1-yorumlayıcı metodunu kullanmıştır.

$\mathrm{Bu}$ bağlamda, zihniyetin önemli bileşenlerinden biri olarak nitelendirdiği din ile iktisadi faaliyet arasındaki ilişkiyi anlamacı yöntem ile kurmaya çalışan Ülgener, Türk modernleşmesinin ana hattını oluşturan Gökalp-Durkheim çizgisi karşısında Ülgener-Weber çizgisini yaratmıştır (Sayar, 1998: 253).

Daha önce de değinildiği gibi, Ülgener'in dünya görüşünün oluşmasında Alman düşünürler, özellikle de Max Weber son derece önemli bir paya sahiptir. Doğu ve bilhassa

7 Ülgener'in çoğu kitap hacmindeki makaleleri "İstanbul İktisat Fakültesi Mecmuası", "Yeni Türkiye”, “İş”, “İş ve Düşünce" gibi dergilerde yayımlanmıştır. Almanca ve İngilizce makalelerinin yanında oldukça önemli sayıda tercümeleri de bulunmaktadır. Bu tercümelerin epeycesi Neumark, Kessler ve Rustow'dandır (Sağlam, 1991: 99).

${ }^{8}$ Ölmüş birinin anısına yazılan yazılar.
Osmanlı Devleti'nde iktisat, ahlâk, zihniyet, kapitalizm, din vb. kavramları ele alan Ülgener, bu konuda da Weber'in çalışmalarından epeyce etkilenmiş ve yararlanmıştır. Bu doğrultuda, öncelikle Weber'in din ve kapitalizm arasındaki ilişki konusunda söylediklerine kısaca bakmak faydalı olacaktır.

Weber'e göre iktisat ahlâkı farklı çă̆ ve zamanlara göre değişiklik göstermiștir. Bazı toplumlarda bu değişiklik olumlu yönde bir gelişme gösterirken, bazı toplumlar bu gelişime ayak uyduramayarak çağın gerisinde kalmışlardır. Protestan toplumu bu gelişmeyi en iyi şekilde takip etmiş ve ileri bir toplum seviyesine ulaşmıştır. Oysa İslâm dini bu gelişmeyi takip edecek tetikleyici faktörlere sahip olmadığı için, Müslüman toplumlar bu gelişmelerin gerisinde kalmışlardır. Weber'e göre düzenli yaşama biçimi insanlık tarihinde belki de ilk defa manastırlarda ortaya çıkmıştır. Çan kulelerinde ibadet zamanını belirtmek için çalan çanlar rahiplerde dakiklik bilincinin oluşmasına neden olmuş ve Batıda ilk dakik yaşayan insanlar rahipler olmuşlardır. Zamanla bu dakiklik bilinci tüm topluma yansımış ve insanların günlük yaşamları üzerinde etkili olmuştur. Böylece dakiklik bilinci insanlarda vazife anlayışının oluşmasını sağlamıştır. Ayrıca Weber İslâm dinini bir "savaşçılar" dini olarak kabul etmekte ve ilk Müslümanların genellikle savaş ganimetinden zengin olmuş varlıklı insanlar olduklarını savunmaktadır. O'na göre Müslümanlar kulluk görevlerini sadece namaz kılmak, oruç tutmak gibi günlük ibadetler yaparak yerine getirmektedirler (Torun ve Duran, 2010: 6869).

Weber'in Protestan ahlâkının kapitalizmi doğurduğu iddiasını Osmanlı'ya uyarlayan Ülgener ise, Weberci kuramsal analizlerle Osmanlı İmparatorluğu'nda kapitalizmin ortaya çıkmasını engelleyen nedenleri araştırmıştır. Ülgener'e göre, Weber İslâm konusunda taraflı davranmaktadır. Oysa İslâm yoğun bir ticaret ortamında gözlerini dünyaya açmıştır; Doğuda modern anlamda piyasa ekonomisinin yerleşip gelişmesine engel olan sebepler peşpeşe sıralanacak olsa, İslâm ancak serinin en sonunda yer alacaktır (Akt: Doğan, 2010: 183; Yılmaz, 2011: 59). Ülgener bu bağlamda Weber'in düştüğü hatayı şu şekilde izah etmektedir:

"İslâm'ın, diğer taraftan, bir kısim tavizlerle beraber, aslında en büyük hasım olarak karşısına aldı̆̆ı hayat tarzını da burada aramak lazımdır: İslâm, mala mal varlı̆̆ından değil kibir ve gurur metası, çokluk yarlşı olduğundan karşıdır; ve de ilave edelim- işin o yanı söz konusu oldu mu öyle çekingen ve tereddütlü değil, sonuna kadar sebatlı ve kararlı olarak karşı! Weber'in ve bir kısım batılı tarihçilerin İslâm' l feodal yapılı bir din olarak takdim ederken düştükleri hata da bizce buradadır: İslâm'ın karşısında olduğunu yanında imiş görme ve göstermeleri... İslâm'in her halde kendini kısa zamanda "dünyaya" uydurmayı başarmış bir din olduğuna şüphe yoktur. Bu uуuти, önünde hazır bulduğu toplum yapısina (özellikle feodal yapıya) körü körüne teslimiyet manasina kadar vardırmamakla beraber, dinin dünya nimetleri karşısında mü'mine oldukça geniş bir yaklaşım payı tanıdı̆̆ rahatlıkla söylenebilir" (Ülgener, 2006c: 66-67).

Weber'in İslâm dinini "savaşçılar dini” olarak nitelendirmesi hakkında ise Ülgener şunları söylemektedir:

"İslâm, ilk Mekke Müslümanlarının gerçekten içe ve derine dönük ivazsı garazsız diyaneti ile beraber Medine'ye atladıktan sonra yolunu kulıçla açacak bir cihad ordusuna ihtiyaç duymuş olabilir ve ona göre çevreye davetini-mesajınt-derinlemesine bir vecd ve takva'dan fetih ve cihada yönelik bir ifade biçimine 
çevirdiği de düşünülebilir. Buraya kadarına denecek bir şey yoktur. Ondan ötesine yollarımı ayrilır. Max Weber'e göre, İslâm cihadla beraber kapalı bir savaşçılar topluluğunun ("kast”ının) ortak inancını oluşturmuştur. Ve asıl önemlisi: Cihad ehli, peygamberin üstün kişiliğine - "karizma" tarafinabağlılıkla beraber, fütühatın getireceği maddi mükafatı ve hele mal mülk sahibi olmanın heyecanını bir motif olarak hiçbir zaman küçümsemiş sayılmazdl. Bununla beraber bütün bir yayılmanın temelinde vurgun ve mal mülk cazibesi aramak ölçüyü taşırmaktan başka sonuç vermeyecekti. Max Weber ki, bir yandan Marksist yazarları ilk Hiristiyanlı̆̆ bir proleter hareketi olarak gördükleri için ağır biçimde tenkit etmişti. Sırası gelip kendisinin de ilk İslâm mücahitlerini aynı derecede maddi-iktisadi çıkar ilişsisine bağlamak suretiyle, tenkit ettiği görüşü tekrarlaması düşündürücüdür" (Ülgener, 2006c: 71).

Ülgener İslâmi metinlerin ve uygulamaların Weber'in iddia ettiği gibi, iktisadi geriliğe yol açmadığını ısrarla ortaya koymaya çalışmış ve İslâmi metinleri, uygulamaları ve özellikle Tasavvuf ahlâkını tarihi ve sosyal şartlara göre yeniden yorumlamıştır. Weber'in aksine, Ülgener'e göre İslâm özünde çalışmaya, akla, ticarete, pazara önem vermiştir. Buna karşın İslâmi özden sapan (özellikle Bâtınî) tasavvuf, esnafla ittifak kurarak yeniliğe kapalı ve direnen gelenekçi insan/toplum tipi oluşturmuştur. Çünkü esnaf ve halk kesimleri arasında yer alan dini ve ahlâki değerlerin büyük çoğunluğu Bâtınî zümre ve tarikatlardan oluşmuş, Alevî-Bâtınî zümreler ahilik ve esnaf üzerinde XIII. yüzyıl gibi erken dönemden itibaren etkilerini hissettirmişlerdir. Ülgener'e göre bu etkiler ayıklanarak, kendi deyişiyle, çağın gereklerine uygun bir İslâm üzerine bir kapitalizm mümkündür (Arslan, 2010: 73-74).

Ülgener, İslâm toplum ve medeniyetinin ikili portresini çizer: Bir yanda çalışkan, dışa dönük, para biriktiren tüccar bir peygamber, diğer tarafta içe kapalı, çalışma ahlâkını geliştirememiş, hizmet ve mal üretiminde kapitalizme geçememiş bir toplum ve medeniyet. $\mathrm{Bu}$ çarpıklı̆̆ın açıklaması ise tasavvufa atıfla yapılır. Ülgener'e göre tasavvuf, İslâm'ın ilk ve öz halinden farklılaşan, “içe ve derine kapanışın uzun ve zahmetli yolunun adıdır" ve İslâm'ın yayıldığı bölge inançları ile İslâmi öğelerin karıştığı genel akımı ifade etmektedir. Tasavvuf 12. ve 13. yüzyıllarda yaygınlaşarak kitlelerin hem dini anlayışını hem de gündelik yaşantılarını etkilemiştir (Arslan, 2010: 56-57). Kalkınma ve gelişme dönemlerinde tasavvuf ahlâkının gelişmeyi, kalkınmayı, tasarrufu, disiplinli çalışmayı ve üretmeyi canlandırdığını; gerileme dönemlerinde ise tembelliği ve ataleti besleyen bir dini algılama biçiminin inşa edildiğini belirtmiştir (Torun ve Duran, 2010: 67). İşte Osmanlı toplumunun asıl geri kalış nedeni de, İslâm'ın ilk saf ve orijinal hali değil de, daha sonraki dönemlerde yer yer iptidai düşüncelerle yoğrulmuş bir mistisizm şeklidir.

Yani Ülgener'e göre tasavvuf, ilk dönemlerinde olduğu gibi dışa açılmanın öncüsü olamamış hatta Anadolu'da uzun süre içe kapanışın öncülüğünü yapmıştır. Ülgener İslâm dininin getirdiği dünyaya bakış tarzı ile ilgili ölçülerin, Melâmilik hariç tutulacak olursa- tasavvufla birlikte negatif anlamda değiştiği görüşünü savunmaktadır. Ülgener'e göre tarikatlar, altlı-üstlü kademe bölünüşleri ile toplum, siyaset ve ahlâk anlayışına (iktisat dâhil) İslâm'da olmayan yeni bir boyut (otorite ve gelenek) eklemişlerdir. Dışa yabancı, içte güven arayan, tarikatlara bel bağlayan bir insan tipi ortaya çıkmıştır. Ülgener, tasavvuf ile İslâm medeniyetindeki üç temel şeyle ilgili algıların değiştiği görüşündedir: eşya, çevre, zaman. Tasavvufla "eşya"ya bakışta diş dünya ile uzakta durulan; "çevre" ye bakışta dışa mesafeli, içle bütünleşme ve küçük cemaat/tarikatlara ilgi duyulan; "zaman" algısında geçmişe ve geleceğe uzak, sadece yaşanan ânı düşünen bir tasavvur dünyası oluşmuştur (Arslan, 2010: 57).

Ayrıca tasavvuf anlayışı içerisinde ikili bir yapı bulunduğunu belirten Ülgener tasavvuf içindeki bu ikiliği "Melâmi ve Batini tasavvuf" adı altında genel bir formülasyona tabi tutar. "Bâtınilik" tasavvufun içe dönük yönünü temsil etmektedir. Osmanlı Devleti'nin geri kalmasının sorumlusu da bu anlayıştır:

"Batıda iş ve meslek adamı için en duyarlı ve canlı alıcı kesime-Kuzey Batı Avrupa ve Kuzey Amerika- dini reformasyonun metodik-disiplinli kanadl (Kalvinizm) ile yanaşması endüstriyel kapitalizm için gerekli tavır ve düşünce iklimini yaratmaya yardımc olurken, tasavvufun beri yanda kalabalık yığınlar ve iş çevrelerine daha çok batini bir yorum çizgisinde hulûl etmesi ayrı bir davranış türüne ve onun da ötesinde değişik bir düzene -rant kapitalizmine- yatkın bir mânâ iklimini yaratmaktan geri kalmamıştır" (Ülgener, 2006c: 137).

"Melâmilik" ise bir taraftan dünyaya yönelişin zararlı tesirleri ile savaşmayı, diğer taraftan da dünya ile meşguliyetin gerekliliğini ifade etmektedir:

"En kısa ve belirgin çizgileri ile söylemek gerekirse: Dünya, Melâmi için, bir haz ve zevk ortamı olmadığ gibi günah ve kusurlarına bulaşmamak için uză̆ında durulması ve kaçınılması gereken "ölümlü dünya" da değildir; tam tersine işlenmek, şekil ve düzen verilmek üzere mü'minin önüne serili bir madde ve malzeme yı̆̆ınıdır. Dünya ki, bir yanı ile, Tanrı'nın madde ve insan halinde zuhuru, onlarla kendini açılayışı... o halde dışına ve uză̆ında değil, rıza ve hoşnutluğunu celbedecek işlerle dosdoğru içinde ve ortasında olmak lazımdır. Fakat dahası var: Dünya diğer bir yanıyla da beşeri ihtirasların birikim ve odak noktası olarak altedilecek bir düşman, bir hasım kuvvet... ama bu haliyle de önünden kaçarak değil, içinde kalıp zararl tesirleri savaşarak alt edilecek bir hasım!" (Ülgener, 2006c: 105).

Görülüyor ki Melâmilikte çalışma ve cehdetme uzak durulması gereken bir insani zaaf değil, tam aksine bir erdem ve vazife bilinci ile yapılması gereken bir görevdir. Yoksa çile, zühd ve diğer yollarla dünyaya boş vermek söz konusu olamaz. Ayrıca Melâmiliğin Ülgener'in analizinin asıl anlamlı kısmını oluşturan, kendilerinin ikinci tip versiyonu olan ve asıl orijinal boyutlara sahip bir akımı idi. Ülgener tarafından bu grup ikinci dönem Melâmiliği olarak nitelendirilmektedir. $\mathrm{Bu}$ akımın da en belirgin-öne çıkan savunucuları ve taraftarları Hacı Bayram Veli'nin kurucusu olduğu Bayramiyye tarikatıdır. Mesela Melâmi şeyhlerinden Ankara'lı Hüsamettin ve İdris-i Muhtefi adıyla da bilinen Şeyh Ali Rumi'nin de aralarında sayılabileceği (Deniz, 2009: 69) bu kişiler şöyle tarif edilmektedir:

"Melamî, Hakk'a yakınlı̆̆ halkın dışında belli bir davranış ve özel klyafetle sergilemeyi asla düşünmeyerek, herkesle beraber ve herkes gibi işi gücü peşinde; kulluğunu ise arada sessiz sedasız yerine getirmekle meşgul! Daha kısacasi: Görünürde halk'la, gönülde Hakk'la beraber! Sade ve son derece gösterişsiz yaşantısı içerisinde çalışma ve üretmenin Kalvinist çizgiden geri kalmayan- tsrarlı takipçisi!" (Ülgener, 2006c: 103).

Son olarak, Ülgener'in tasavvufun homojen bir yap1 arz etmediğini, kendi içinde farklılıklara sahip olduğu görüşünü ileri sürdüğü belirtilmelidir. Ancak, Melâmiliğin belli kesimler dışında tabanda yaygınlaşamaması gibi nedenlerden ötürü, genel hatları itibariyle tasavvufun İslâm'ın tipik 
gelişim çizgisi ile paralellik göstermediğini ifade etmektedir. Ona göre, bu durumun doğurduğu iktisadi zihniyet nedeni ile Osmanlı toplumu çözülmüştür (Arslan, 2010: 58). ${ }^{9}$

Kısacası, Ülgener'e göre de fütüvvet, ahilik ve lonca birlikleri, topluluğu, iş ahlâkı ve vazife ruhu doğrultusunda kontrol etmekte, göreneği korumakta ve dışarıya kapanmayı desteklemektedir. $\mathrm{Bu}$ doğrultuda, Osmanlı insanının davranışsal portresi de, maddeye ve hayata karşı ilgisiz, merak duygusu zayıf, ömrünü iş-güç kaygısıyla geçirmekten hoşlanmayan, bütün işlerinde ve kararlarında göreneklere ve geleneksel otoriteye sıkı sıkıya bağlı bir tip olarak resmedilir (Çelik, 2003: 667). Bu özellikleri dolayısıyla ahilik Ülgener'in belirttiği üzere Osmanlı toplumunun biraradalığına katkıda bulunur; fakat göreneğe, alışkanlığa ve rutine yaptığı vurguyla kapitalist bir çalışma ideolojisinin gelişmesine engel teşkil eder. $\mathrm{Bu}$ verilerden yola çıkarak Ülgener, Osmanlı'da kapitalizmin gelişmemesini, eşraf ve esnafın zihniyet dünyalarındaki bu muhafazakârlığa ve kapalılığa bağlar. Bu prekapitalist ahlâki görüşler toplamına da "Ortaçağ Zihniyeti" der (Akt: Demir, 2008).

Gelenekçilik, Ülgener'e göre, üretim tarzı ve tekniği açısından kati bir muhafazakârlıkla tezahür eder. Bu muhafazakârlık geriye ve göreneğe bağlllıkta en yetkin ifadesini bulur. Ülgener'e göre, sanat ve meslek âdâbı yüzyıllar boyunca aynı kaldığı gibi, o usullerin tatbikine yarayan teknik vasıta ve ameliyelerde de olagelmişten en küçük inhirafa göz yummak imkânsızdır. Gelenekçiliğin ikinci tezahür alanı sosyal yapıdır. Üretim tarzı ve tekniği açısından görenekçilik (empirizm) ve pir ve ustalara bağlılık söz konusuyken, sosyal yapı ve hiyerarşi açısından rütbe ve kademece alttan üste bağlılık ve teslimiyet esastır. İlkinde muhafazakârlık mesleği bilindiği ve öğretildiği gibi (yani, öncekilerden devralındığı gibi) korumak olarak yansırken, sosyal yapı ve hiyerarşi bağlamında ikincisi, öğreticiye hürmet ve riayet anlamına gelir. Böylelikle görenekçiempirik meslek ve üretim tarzı disiplin altına alınmış ve otorite aracılığıyla söz konusu disiplin korunmuştur. Ülgener otorite ve hiyerarşinin ortaçağ toplumsal hayatı ve düzeninin vazgeçilmez şartlarından olduğunu vurgular (Özkiraz, 2007: 48).

Ülgener'e göre gelenekçi toplumlar; değişmelerden, özellikle teknik ilerleme, yer ve meslek değiştirmelerden

9 Ülgener, "çözülme devri" tabirini, Osmanlı İmparatorluğu'nda 15. ve 16. yüzyıllardan itibaren başlayan süreç için kullanır. Batı, Atlantik kıyılarında yeni ticaret yolları bulması sayesinde gelişirken, Osmanlı İmparatorluğu Akdeniz çevresindeki ticaretin ve girişimciliğin sona ermesiyle gerilemeye başlar. Akdeniz'de girişimcilik ve sermaye adına olan tüm birikim Batı limanlarına yığılır. Bunun Osmanlı İmparatorluğu'ndaki yansıması "çözülme" olarak belirir. Başka bir deyişle çözülme, dişsal kaynaklıdır ve esas nedeni ulaşım yollarının değişimiyle ilintilidir. Coğrafi keşiflerle birlikte başlayan bu dönüşümün Osmanlı üzerindeki etkisi ancak esas olarak 16. ve 17. yüzyıllarda hissedilecektir. Çözülme devri dünya ticaret yollarının Akdeniz'i kaderi ile baş başa bırakıp Atlantik kıyılarına doğru yer değiştirmeleri ve bunun zihniyet dünyamızda bıraktığı izleri anlatır (Öztürk, 2006: 91). fazlaca hoşlanmayan bir zihniyete sahiptirler. İktisadî bakımdan geleneksel bir toplumdan modern bir topluma geçebilmenin başlıca şartı, insan-eşya ilişkilerinde görülen geleneksel değer anlayışını değiştirebilecek bir zihniyet ortamına varabilmektir (Özkiraz, 2007: 56). Bunun yolu ise, Ülgener'e (2006d: 58-59) göre: 1) Serveti ve parayı şahsa bağlı, onunla âdetâ içli dışlı bir varlık gibi görmekten vazgeçip, ferah ve açık yürekle piyasa ekonomisine çıkmayı her türlü eğri ve kuytu kazanç şekillerine üstün sayabilmek; 2) Kazancını yine şahsa ve statüye bağlı olarak göstermelik tüketim veya verimsiz yatırıma harcayacak yerde, profesyonel iş adamı olarak prodüktif yol ve şekillerde verimlendirebilmek, ve nihayet 3) Bütün bu faaliyetlerde disiplinli, kontrollü bir hesap ve muhasebe şuurunu tesis edebilmek ile yakından alakalıdır.

Görüldüğü üzere, Ülgener Cumhuriyet'in “öteki”si olarak sunulan geleneksel ve tepkisel muhafazakârlığın (irticanın) kökenindeki halk İslâm'ı/tasavvuf ile onunla iç içe geçmiş esnaflığı "ortaçağlaşmanın" aktörleri olarak tahlil ve tenkit ederken, Türk muhafazakârlığındaki Osmanlı güzellemesinden uzaktır. Osmanlı Devleti'nin yükseliş aşamasındaki yüksek idari teşkilatlanmaya rağmen, daha o dönemde tasavvuf ve esnaflaşmayla ortaçağlaşma sürecine girdiğini söylemektedir. Bu bağlamda, Türkiye örneğinde muhafazakârlık, gerçekleşen sanayileşmeye karşı çıkmak istikametinde değil, tam aksine toplumsal hiyerarşide tepede yer alan bürokrasinin yerini değiştirmek ve yükselmek amacıyla ihtirasla sanayileşmek yönünde gelişmiştir. Ülgener, bu noktada geleneksel ve tepkisel muhafazakârlığın kaynağını eleştirirken, Cumhuriyet'in bürokratik muhafazakârlığını da eleştirmektedir. "Piyasa" ilişkilerinin yaygınlaşmasıyla ortaya çıkacak olan rasyonel insan tipinin ve yeni sınıfların, Kemalizmin dolduramadığı moral zemin eksikliğinin, İslâm'ın ilk ve öz halinde mevcut olan "kapitalistleşmeye açık" İslâm'ın konularak aşılacağını düşünmektedir (Yılmaz, 2003: 490-491; Y1lmaz, 2011: 80). Ülgener'in muhafazakârlığı, "iman” (subjektif bilgi) ile "aklı" (objektif bilgi) uzlaştıran, ahlâk ile kapitalizmin rasyonalitesini birleştiren bir öze sahiptir. Onun "insan-1 kâmil"i, tevekkül ve tecelli içinde "hayatı metodik, hesaplı bir iş ve vazife ahlâkını zihnine dokumuş" kişidir (Yazıcıoğlu, 2008: 3).

\section{Sonuç}

Sabri Ülgener, pek çok açıdan artık yaşayan örneklerine fazla rastlamadığımız, bütüncül ilim adamlarımızdan biridir. İktisat bilir, sosyoloji bilir, tarih bilir, felsefe bilir, bunların birlikte değerlendirilmesi gerektiğinden haberdardır. $\mathrm{Bu}$ disiplinlerin her biriyle ilgili görüşleri ve analizleri vardır. $\mathrm{Bu}$ alanların hepsini bir arada ele alamayan, disiplinler-arası yaklaşımın önemini kavramamış, öteki ilim dallarının yöntem ve bulgularından istifade etmeyen tahlillerin yetersizliğinin farkındadır. Batıyı da, Doğuyu da tanıyan, ufku geniş bir alimdir Ülgener. Marx'tan da haberdardır, Gazali'den de. Bir devirden diğerine toplumsal dönüşümü açıklamak, kendimizi anlamak ve sağlam bir zemine dayanarak geleceğe yön vermek derdindedir. Körükörüne Batıcı da değildir, gözükapalı Doğucu da. Yeri gelince her ikisini de övmesini bilir; yeri gelince yermesini de.

Eserlerinin önemli bir kısmında bir zamanlar kendi iç dengelerini kurmuş ve refaha ermiş bir toplum iken nasıl olup 
da çözüldüğümüz, dengemizi şaşırdığımızı açıklamaya çabalar. Bu bağlamda Ülgener'e göre iktisadi çözülmemizde etkili olan insan portresi kabaca şudur: Bol ve ferah yaşamanın tattıracağı haz ve zevkin yabancısı olmamakla birlikte, o uğurda acele ve telaştan hoşlanmayan, yolunu ve yönünü tayinde görenek ve otorite bağları ile çevrili, dışa ve "yaban"a kapalı, ve nihayet, işinde ve hesabında "götürü" insan.

Zihniyet, Ülgener'in anahtar kavramlarından biridir. Ne sadece maddi unsurlara yüklenerek Marx'a şakirdlik yapar; ne sadece din ve kültür diyerek Weber'e yaslanır. Bu unsurların her ikisini de kapsayan, yoğuran, anlamlandıran, ete-kemiğe büründüren zihniyettir önemli olan. Zihniyet değişti mi, insan da değişir, toplum da. Ortaçağ'dan sonra Batı ile Doğu'nun izlediği farklı gelişme çizgilerinde işte bu zihniyet farkının belirleyici bir önemi vardır. Zihniyet o kadar merkezi bir kavramdır ki Ülgener için, eserlerinden yarısının doğrudan başlığına da yansımıştır.

Batıda Rönesans ve Reform hareketleri, beșeri aklın bütün manevi, ruhani otoritelerini yıkarak, bireyi din ve sanat alanında "vahiy ve ilhamını Allah'tan aracısız alma" olarak değerlendirilebilecek bir olgunluk seviyesine kavuşturmuştur. Bu sayede iktisadi hayatta da rasyonalizmin temelleri atılmış; bu alanda da artık sanatın üzerindeki kalın esrar perdesi kalkmış, her sanatın, diğer ilimler gibi görenekle, yani eskileri ve ustaları taklit ederek değil, aklın ve mantığın yardımıyla öğrenilebilmesi kolaylaşmıştır. Oysa bizde çeşitli tasavvufi unsurlarla -tasavvufun Melâmi değil Bâtıni versiyonuyla- birleşerek daha kapalı, daha taklide dayalı, daha hesapsız, plansız, üstünkörü yaşama zihniyeti hayli zaman egemen olmuştur. İktisadi çözülmemizde bu anlayışın etkisi büyüktür.

Ancak Ülgener Batı ile aramızdaki zihniyet farkını bu şekilde ortaya koymakla birlikte, ülkemizde bu insan profilinin son zamanlarda yavaş yavaş değişmeye başladığının da farkındadır. Bu çerçevede Anadolu'da ticaret ve sanayinin canlanması, Kayseri ve Konya örneklerinde olduğu gibi, yeni şehirlerin hızla yükselmesi, piyasanın dinamizmi ve Türkiye'nin 2000'li yıllarda içine girdiği hızlı

\section{Kaynakça}

ARSLAN, Mustafa (2010). "Ülgener'in Dikotomik Yönteminde Meslek Ahlâkı ve Ahilik”, İnönü Üniversitesi İlahiyat Fakültesi Dergisi, Cilt 1, Sayı 1, ss. 55-77.

ÇIZAKÇA, M. ve M. AKYOL (2012), Ahlâki Kapitalizm, İstanbul: Ufuk Yayınları.

ÇELIK, Celaleddin (2003). "İslam İktisat Ahlâkına Dair Birbirini Tamamlayan Bakıș Açıları: Weber ve Ülgener Üzerine Karşılaştırmalı Bir İnceleme”, İslâmi Araştırmalar Dergisi, Cilt 16, Say1 4, ss. 660-671.

DEMIR, İsa (2008). "Türkiye'de Kapitalizmin Gelişimi ve Çalışma Ahlâkı", Sosyoloji Notları içinde, ss. 3-12.

DENIZ, Ergün (2009). Sabri Fehmi Ülgener'in İktisadi-Felsefi Anlayışı, Ankara Üniversitesi Sosyal Bilimler Enstitüsü Felsefe ve Din Bilimler Anabilim Dalı Yayımlanmamıș Yüksek Lisans Tezi.

DOĞAN, Necmettin (2010). "Türk Düşüncesinde 'Mani-i

Terakki' Meselesi”, İstanbul Ticaret Üniversitesi Sosyal Bilimler Dergisi, Y11: 9, Say1: 17, ss.177-187.

ERTÜZÜN, Tevfik (1987). "Prof. Ülgener'in İktisadi Kalkınma Yaklaşımı", İstanbul Üniversitesi İktisat Fakültesi Mecmuası, Cilt

43, Prof. Dr. S. F. Ülgener'e Armağan, ss. 13-25.

KOÇDEMIR, Kadir (1998). "İlmiyle Alim, İrfanıyla Arif; Ülgener”, Türkiye Günlüğ̈̈̈, Sayı 51, ss. 107-116. toparlanma süreci, başka bazı faktörler yanında, dışa açılma, dünya ile barışma ve zengin olmanın dini inançlarla çelişmediği anlayışının benimsenmesiyle yakından irtibatlıdır. Son olarak Ülgener, dinin toplum hayatındaki yeri ve İslâm dininin piyasa ile barışıklığı konusunda, MarxWeber tartışmasına -her iki düşünürden de belirli noktalarda ayrılarak- katkıda bulunur.

Marx'a göre din halkların afyonudur; toplumları değiştiren şey, “üretim tarzı"nda ifadesini bulan maddi faktörlerdir. Weber bu görüşe itiraz eder. Weber'e göre dinikültürel faktörler toplumların değişiminde anahtar rol oynarlar. Kapitalizmin yükselişine öncülük eden -çok çalışma, tasarruf ve zengin olarak Tanrı katında seçkin bir kul olduğunu gösterme çabasıyla tezahür eden- Protestan ahlâkı ve Kalvinizm'dir. Bu konuda Batıyla ilgili kayda değer tahliller yapan Weber, aynen Marx gibi, Doğu ve İslâm dünyası konusunda ne yazık ki isabetsiz ve sığdır. Weber'e göre İslâm kapitalizmin önünde bir engeldi, çünkü yalnızca cihadı ve dünyevi zevklerden uzak bir hayatı teşvik ediyordu; İslâm savaşçı ve yağmacıların diniydi... Çizakça ve Akyol'un (2012: 16-17) tespitleri bu tartışmaya Ülgener'i de dâhil ederek değerlendirme bağlamında gerçekten kayda değer:

"Weber Hristiyan olmayan toplumlar üzerindeki analizlerinde yanılıyordu, çünkü yöntemlerinin daimi olacağını sanıyordu, kısmen de tarihlerini yanlış analiz etmişti. Büyük Türk sosyologlarindan biri olan, Weber'in hem ögrencisi, hem de muarızı olan Sabri Ülgener'e göre, Weber, Batı kapitalizminin kaynaklarını incelemede sergilediği dehâya rağmen, İslâm' $ı$ çok yanlış değerlendirmiş ve İslâm dininin serbest piyasa sistemiyle fitri bağdaşıklı̆̆ını küçümsemiştir."

Düşünce dünyamızın mümtaz şahsiyetlerinden olduğu kuşku götürmeyen merhum Ülgener bugün hayatta olsa, vaktiyle teorik planda savunduğu tezlerin realite tarafından desteklendiğini, bu çerçevede Özal sonrasında yaşanan zihniyet dönüşümünün Türkiye'yi de dönüştürdüğünü görecekti. Türkiye'nin Ülgener çapında, entelektüel derinliği müthiş, ufku geniş, kılı kırk yaran titizlikte, ilim ahlâkı ve analiz kabiliyeti yüksek ilim adamlarına çok ihtiyacı var.

SAĞLAM, Serdar (1991). "Bir Aydın, Sabri Ülgener”, Türk Yurdu, Cilt 11, Say1 44.

SARC, Ömer Celal (1987). "S. F. Ülgener'in Kişiliği ve Eseri Hakkında", İstanbul Üniversitesi İktisat Fakültesi Mecmuası, Cilt 43, Prof. Dr. S. F. Ülgener'e Armağan, ss. 1-2.

SAYAR, Ahmed Güner (1987). "Sabri Ülgener'in Bıraktığ Miras", İstanbul Üniversitesi İktisat Fakültesi Mecmuası, Cilt 43, Prof. Dr. S. F. Ülgener'e Armağan, ss. 27-34.

SAYAR, Ahmed Güner (1998). Bir İktisatçının Entellektüel Portesi: Sabri F. Ülgener, Eren Yayıncılık, İstanbul.

SAYAR, Ahmed Güner (2008). "Prof. Dr. Sabri F. Ülgener Hayatı ve Eserlerine Dair Özet Bir Sergileme", İş Ahlâkı Dergisi, Cilt 1, Say1 1, ss. 123-136.

ÖZKIRAZ, Ahmet (2000). Sabri F. Ülgener'de Zihniyet Analizi, a yayınevi: Ankara.

ÖZKIRAZ, Ahmet (2007). "Sabri F. Ülgener'de Zihniyet ve Geri Kalmışlık”, İ. Ü. Siyasal Bilgiler Fakültesi Dergisi, No: 36, ss. 35-59.

ÖZTÜRK, Serdar (2006). "Bir İktisatçının Türk İletișim Araştırmalarına Katkıları: Sabri Ülgener Üzerine Notlar”, Ekonomik Yaklaşım, Cilt 17, Sayı 58, 89-113.

TORUN, Fatma; DURAN, Hacı (2010). "Sabri F. Ülgener ve İki Eseri Üzerine Bir Değerlendirme", İstanbul Üniversitesi Sosyoloji Konferansları, Sayı 42, ss. 63-75. 
TUNA, Orhan (1987). "Prof. Dr. Sabri F. Ülgener ve İki Eseri”, İstanbul Üniversitesi İktisat Fakültesi Mecmuası, Cilt 43, Prof. Dr. S. F. Ülgener'e Armağan, ss. 3-12.

ÜLGENER, Sabri F. (1995). Milli Gelir, İstihdam ve İktisadi Büyüme, Der Yayınları, İstanbul.

ÜLGENER, Sabri F. (2006a). Tarihte Darlık Buhranları ve İktisadi Muvazenesizlik Meselesi, Derin Yayınları, İstanbul.

ÜLGENER, Sabri F. (2006b). İktisadi Çözülmenin Ahlâk ve Zihniyet Dünyası, Derin Yayınları, İstanbul.

ÜLGENER, Sabri F. (2006c). Zihniyet ve Din: İslâm, Tasavvuf ve Çözülme Devri İktisat Ahlâkı, Derin Yayınları, İstanbul.

ÜLGENER, Sabri F. (2006d). Zihniyet, Aydınlar ve İzm'ler, Derin Yayınları, İstanbul.

ÜLGENER, Sabri F. (2006e). Makaleler, Yayına Hazırlayan Ahmed Güner Sayar, Derin Yayınları, İstanbul.

YAZICIOĞLU, Eda (2008). İktisadi İnhitat Tarihimizin Ahlâk ve Zihniyet Meseleleri Üzerine Bir İnceleme, YBAD Lisansüstü Seminer Çalıșmaları, $\quad$ No: http://yonetimbilimi.politics.ankara.edu.tr/files/2013/07/edayaziciog $\underline{\text { lu.pdf }}$

YILMAZ, Murat (2003). "Sabri Fehmi Ülgener", Modern Türkiye'de Siyasi Düşünce V: Muhafazakârlık içinde, Editör Ahmet Çiğdem, İletişim Yayınları, İstanbul, ss. 490-508.

YILMAZ, Murat (2011). "Sabri Fehmi Ülgener ve Muhafazakârlık", Sabri Fehmi Ülgener: Küreselleşme ve Zihniyet Dünyamız içinde, Editör Murat Yılmaz, T. C. Kültür ve Turizm Bakanlığı Yayınları, Ankara, ss. 47-83.

YÖRÜK, Ahmet (1987). "Prof. Dr. Sabri F. Ülgener", İstanbul Üniversitesi Iktisat Fakültesi Mecmuası, Cilt 43, Prof. Dr. S. F. Ülgener'e Armağan, ss. XV-XXIV. 